\title{
Unpacking Firm Effects: Modeling Political Alliances in Variance Decomposition of Firm Performance in Turbulent Environments ${ }^{(1)}$
}

\author{
Rodrigo Bandeira de Mello* \\ Universidade do Vale do Itajaí - UNIVALI \\ Biguaçu, SC, Brazil \\ Rosilene Marcon \\ Universidade do Vale do Itajaí - UNIVALI \\ Itajaí, SC, Brazil
}

\begin{abstract}
In this paper, firm heterogeneity in turbulent environments is addressed. It is argued that previous studies have not taken into account effects of a turbulent environment, like the Brazilian context, in which firms must face a weak and erratic government. In such an environment, the large portion of variance usually attributed to firm effects may be explained, not by the usual assumptions of mainstream scholars, but by a more 'political' view of firm differences, namely, the ability to manage valuable political alliances. To account for these differences, a multivariate performance measure was construed and a new factor, 'politics effects', has been introduced to the usual model. Company donations for campaign funds in elections was used as a proxy for this factor. A sample of 607 observations, of 177 firms in 15 sectors was used. Results suggest that the presence of politics effects were found to be not significant (using COV and Hierarchical ANOVA). However, different from previous studies, transient industry effects appear to be more important than stable effects. Findings also indicate that a better model specification for turbulent environments is needed and highlight the importance of the cost of capital.
\end{abstract}

Key words: firm heterogeneity; variance decomposition; firm performance; turbulent environments; political strategies.

Received 30 November 2004; received in revised form 21 December 2004.

Copyright (C) 2005 Brazilian Administration Review. All rights reserved, including rights for translation. Parts of this work may be quoted without prior knowledge on the condition that the source is identified.

\footnotetext{
* Corresponding author: Rodrigo Bandeira de Mello
}

Universidade do Vale do Itajaí - UNIVALI, Programa de Mestrado Acadêmico em Administração, Rua Patrício Antonio Teixeira, 317, Jardim Carandaí, CEP 88160-000, Biguaçu, SC, Brazil.

Tel: +55 48279 9552; fax: +55 482799555 . 


\section{INTRODUCTION}

Firm heterogeneity is a fundamental issue for strategy scholars. Why and how firms sustain a competitive advantage over competitors and benefit from superior returns are important questions of the research agenda (RUMELT; SCHENDEL; TEECE, 1994). This paper addresses the issue of firm heterogeneity in turbulent environments, specifically when turbulence is generated mostly by the influence of government at all levels, such as the case of the Brazilian context.

Mainstream literature on strategy usually considers environmental turbulence as a characteristic of highly competitive environments, in which rapid technological changes take place and where entrepreneur firms strive to reach sustainable competitive advantage positions (BROWN; EINSENHARDT, 1998; PRAHALAD; HAMEL, 1990).

However, one may argue that, for firms operating in Brazil, environmental turbulence is better explained by hostile governmental influences on a firm's business environment rather than by competitive moves of entrepreneur firms operating in highly competitive environments.

The question of how different forms of government influence organizing and strategizing has received scant efforts by strategy scholars. "Certainly, the fact that scholarship and research is dominated by those living in societies with comparatively strong, predictable, and supportive governments has played a part in this omission' (PEARCE, 2001, p. 2). These government characteristics are peculiar to modern societies and to what Pearce (2001) defines as facilitative governments. In such a context, institutional stability and law enforcement are taken-for-granted assumptions that underlie the rationale of investors in which their patent rights will be further assured. On the other hand, Pearce (2001) defines non-facilitative governments as being erratic in the formulation of laws, weak in their enforcement, and hostile to the independent organization. These government actions may cause environmental instability to firms, difficulties in forecasting potential opportunities, threats to their success, and, hence, the way they organize themselves.

Therefore, theoretical perspectives on strategy - which have been built and validated in facilitative government contexts (using Pearce's definition) - do not take into account influences on the firm's organizing and strategizing, of environmental turbulence inherent to non-facilitative governments.

This is the case of firm heterogeneity research. In general, heterogeneity is analyzed through the decomposition of performance variance in sound conceptual factors, named industry, year, corporate and firm effects (McGAHAN; PORTER, 1997; 2002; ROQUEBERT et al., 1996; RUMELT, 1991; SCHAMALENSEE, 1985). Despite the fact that most of these studies have been conducted in the context of developed countries and facilitative governments, their findings have been used to support theoretical perspectives on strategy, namely the Resource-Based View (RBV) of the firm and perspectives drawn from the Industrial Organization (IO) tradition (MCGAHAN; PORTER, 1997; RUMELT, 1991). One may deduct from the above paragraph that descriptive models of firm heterogeneity should be elaborated to account for characteristics of turbulent environments.

A notable exception is the work of Brito and Vasconcelos (2003b), using Brazilian firms. Their findings suggest that turbulence inherent to the Brazilian environment does not affect the structure of variance decomposition found in previous studies abroad. Even though they had expected more importance to the effects of yearly macroeconomic fluctuations and shocks, firm effects were found to be more important than industry effects, and year effects were not significant. The authors then concluded that in conditions of extremely environmental turbulence, managers should focus on what their firms do best, since this would be more important than to be in the right sector or to take advantage of economic shocks and changing rules.

One may argue that, in an effort to deliver comparable results, Brito and Vasconcelos (2003b) used a descriptive model that was not able to fully capture the influence of a turbulent environment on performance variance. In this paper, this argument is pushed forward by analyzing an alternative 
model to turbulent environments, in which turbulence is caused by the hostile influences of the government. This model specification is done in two ways: first, a multivariate metric for firm performance is construed using different indicators; second, the amount of variance attributed to the so-called firm effects - which account for more than one third of total observed variance, according to studies abroad (MCGAHAN; PORTER, 2002), and to almost two thirds in the Brazilian study (BRITO; VASCONCELOS, 2003b) - is considered to be 'packed' in previous models. By 'unpacking' this variance, the intention is to verify their nature. This means posing the following question: in turbulent environments, in which turbulence is caused by hostile influences of weak and erratic governments, can the variance usually attributed to firm differences have the same nature as their counterparts of a more institutionally stable, context of munificent, strong and predictable government? Put differently, in such a turbulent environment, is it correct to assume that this large portion of variance is due to differences, which are traditionally proposed by mainstream scholars, such as firm differences in exploitation of competitive resources, competitive positioning, efficiency in using knowledge-based resources in innovation processes, and even, differences in managerial competencies?

This paper tries to answer this question by assuming a plausible hypothesis that this 'traditional' view of firm effects does not explain the whole picture in countries like Brazil. More specifically, in such turbulent environments, firm performance variance usually attributed to firm effects would be better explained by differences in building and sustaining valuable political alliances with the powerful. Therefore, the proposed model 'unpacks' the firm effects variance component, to separate these 'political' effects from the 'traditional' firm effects.

In the following sections of this paper, conceptual and empirical supports for this hypothesis are presented, as well as methodological aspects for its empirical examination. First, a brief review of some previous studies on variance decomposition of firm returns is presented in the next section.

\section{REVIEW OF SOME Studies ON THE VARIANCE DeCOMPOSITION OF FirM RetURNS}

The intention is not to make an extensive or exhaustive literature review, but to address aspects of some relevant studies to the present research. Variance decomposition of firm returns in the strategy field was inaugurated by the seminal paper of Schmalensee (1985) and further advanced by Rumelt (1991). Since then, several other researches have attempted to analyze firm heterogeneity through variance decomposition of firm performance. None of them have tried to impute causal relationships on drivers of performance, but have merely intended to describe the relative effect of sound conceptual factors on performance variation.

Modeled factors are usually called industry effects, year effects, transient industry-year effects, corporate effects and firm effects. Industry effects refer to the contribution of a specific industry to the overall firm performance due to stable industry structure features, such as barriers to entry, product differentiation and the bargaining power of buyers and suppliers. If these effects correspond to a large amount of performance variation, then industry differences are important in describing performance variation, as is advocated by IO Economics derived perspectives (CAVES; PORTER, 1977; OSTER, 1990; PORTER, 1980). Year effects reflect macroeconomic fluctuations that may affect all firms in a particular year, such as a good or bad crop, economic shocks and the volatility of interest rates. Interactions between year and industry capture transient industry effects, or the extent to which yearly macroeconomic fluctuations affect particular industries differently. Corporate effects were of interest because of the corporate diversification phenomena. They capture stable firm differences due to its corporate membership, implying that corporation competencies can be shared among its businesses. Finally, stable firm effects capture any difference in firm performance that can be attributed to idiosyncratic firm differences, such as organization processes, resource exploitation, competitive positioning, organizational efficiency and managerial competency. If firm effects are important, then firm differences, like those proposed by the Resource-Based View, matter in describing firm 
heterogeneity (BARNEY, 1986, 1991; DOSI; NELSON; WINTER, 2000; NELSON; WINTER, 1982; PETERAF, 1993; WERNEFELT, 1984).

Despite methodological differences and the purpose of using the findings as empirical evidence to support different theoretical strategy perspectives, Brito and Vasconcelos (2003b) found that these past studies (their own work included) have some degree of convergence, and suggested that theoretical perspectives on strategy should be used in a complementary manner.

The first work in the series was published by Schmalensee (1985), who sampled diversified manufacturing firms, using their business units' returns in one year as data on performance. The author found that industry effects accounted for $20 \%$ of observed variance. Other modeled factors revealed that corporate effects ${ }^{(2)}$ were not significant and that differences in performance due to differences in market share captured less than $1 \%$.

Using a more complex model than the one used by Schmalensee (1985), Rumelt (1991) modeled, besides industry and corporate effects, year effects and, what he defined as firm effects. Using a sample of diversified manufacturing firms, he used data on business unit returns for a four-year period. His model was then able to capture stable firm differences. He found that, of the total observed variance, $34-46 \%$ was attributed to firm effects and 8-18\% to industry effects. Year effects were found to account for a negligible portion, while transient industry-year effects accounted for $9-10 \%$ of total observed variance. Rumelt (1991)'s work was used to question the importance of industry effects and to support the RBV assumption of firm differences as an important aspect to explain sustained competitive advantage.

McGahan and Porter (1997), and later in McGahan and Porter (2002), used more complex models and robust statistical methods to assess firm performance variance. They modeled serial correlation and covariation among the effects. In both papers they used COMPUSTAT business segment reports instead of the Federal Trade Commission Line of Business (FTC LB) database, used in previous studies. Data covered 14 years of business segment performance in several industries, excluding the financial sector. Firm effects were captured by variation across business segment returns, as they correspond to differences in 'market share, differentiation, heterogeneity in fixed assets, differences in organizational effectiveness, heterogeneity in activity configurations, anomalies in accounting practices, and differences in managerial competence' (MCGAHAN; PORTER, 1997, p. 17). In the 1997 paper, the authors found that industry effects accounted for around $19 \%$ of total observed variance, while firm effects accounted for $32 \%$. In the more recent paper, using simultaneous ANOVA, serial correlation adjusted effects were $0,4 \% ; 10,3 \% ; 11,6 \%$ e $36 \%$, respectively for year, industry, corporate and firm effects. The following conclusions were drawn: (a) firm effects are more important than year, industry and corporate effects; (b) year effects account for a negligible portion of variation in firm performance; (c) the relative importance of year, industry, firm and corporate effects differ across industries; (d) the choice of industry by diversifying corporate parents is related to the industry performance; (e) superior returns tend to persist to the next year since industry, corporate and firm effects are related temporally.

In Brazil, Brito and Vasconcelos (2003a; 2003b) published two notable works. In Brito and Vasconcelos (2003a), the authors provided empirical grounds for the importance of geographic location, by adding to the model a new class of effects related to country. They concluded that 'location does have a saying in explaining part of the observed variance of performance among firms in different economic and industry sectors, throughout the world.' (BRITO; VASCONCELOS, 2003a, p. 12). In a large sample of firms in 78 different countries, they found that country matters most in economic sectors more related to geography such as agriculture, mining and construction.

In the second paper, Brito and Vasconcelos (2003b) modeled performance of firms operating in Brazil as a linear function of year, industry and firm effects, as well as a transient industry-year effect. According to the authors, a greater contribution from year effects was expected due to the turbulent dimension of the Brazilian environment. However, the results were convergent to previous studies: year effects did not show statistical significance and accounted for a small portion of variance in 
performance; and firm effects were more important than industry effects. They further their conclusions by remarking that 'focus on individual firm capabilities and resources that affect performance are even more important, in turbulent environments. Being in the 'right' sector so as to 'take advantage' of certain economic shocks and changing rules does not find sound statistical support. Being good at what you do is still, and maybe even more that ever, the golden rule' (BRITO; VASCONCELOS, 2003b, p. 13).

Two interesting aspects from Brito and Vasconcelos (2003b) can be highlighted. First, firm effects were found to account for two thirds of total observed variance, while in previous studies they accounted for one third. One might argue that this could be attributed to uncontrolled corporate effects in the model which cannot be completely ruled out, even if the sample consisted only of firms in sectors 'known not to be greatly diversified' (BRITO; VASCONCELOS, 2003b, p. 8).

Second, and more important to this paper, the consideration of the nature of the firm effects might entail misleading conclusions. If it is assumed that firm effects are 'packed' in Brito and Vasconcelos (2003b)'s model, then the authors must have followed the same assumptions of foreign studies concerning the nature of these effects to draw their conclusions. The argument here is that one cannot follow the same assumptions because the models used in previous studies do not take into account variation in firm performance due to environmental turbulence, such as that which is peculiar to Brazil, where turbulence is mostly caused by the hostile influence of weak and erratic governments. Therefore, further model specifications should be made to 'unpack' the variation attributed to firm effects.

One possible solution is verified here. In Brito and Vasconcelos (2003a), they have suggested that country matters, therefore, one may also argue that it could be more than geographic location itself that affect performance variation of firms worldwide, but something else, such as differences in how local government influences the business environment and the way firms are organized. In the next section, this argument is discussed more deeply.

Another paper in variance decomposition, published by Hawawini et al. (2003), used different performance indicators from previous studies. The authors used a model similar to Rumelt (1991), but without corporate effects, and measured performance by economic profit, total market value and the traditional measure of return on assets. Their results were convergent with previous studies.

\section{The Political AllianCEs Hypothesis}

Considering that firm effects account for the largest portion of firm performance variance, even in a context of extremely turbulent environments, one may argue that this variance cannot be considered as being caused by firm differences in the aspects usually suggested by mainstream theoretical perspectives in strategy, such as competitive resource exploitation, organizational processes, and efficiency, and competitive positioning.

But, one may think of the nature of such variance in turbulent environments as having a political-like nature rather than a competitive one. This implies that the competitive-like nature does not fully describe managerial efforts that conduct firm differences in performance, as much as the political-like nature does, which assumes that managerial efforts seek to build, monitor and renew valuable political alliances with the powerful.

The problem is to separate, or unpack, these two aspects, the 'political' view of firm effects and the 'competitive' view, so that better conclusions can be drawn on the nature of firm effect variance. More specifically, it is expected that a significant part of the variance accounted for the firm effects is due to differences across firms in building and sustaining these valuable political alliances. In this section, conceptual and empirical support for this assumption is provided. 


\section{The Context of Highly Governmentally Influenced Turbulent Environments}

An environment is considered as having a high complex dimension to the extent to which it demands sophisticated organizational knowledge of consumers and products, and is difficult to be broken down into smaller, more comprehensible units (MINTZBERG et al., 1998). In other words, a complex environment demands organization to understand the diversity of existing relationships among environmental actors. When the structure and nature of such complex relationships changes frequently, as well as complex, the environment is less stable, or dynamic. Complexity and low stability characterize turbulence and, hence, produce uncertainty in organizations (EMERY; TRIST, 1965).

The concept of environmental turbulence considered here includes, besides the complexity and stability dimension, the hostile dimension. In a hostile environment, powerful environmental actors threaten the ability to survive and to develop of firms that have low power to influence the environment in their own favor (MERZ; SAUBER, 1995).

A complex, dynamic and hostile, and therefore turbulent, environment encounters similarities to what Pearce (2001) describes as being the context of non-facilitative governments - NFG. Pearce (2001) defines NFG in three dimensions: (a) hostile - munificent: NFG are hostile to the independent organization (that which is not under the direct control of the government and is free to establish its own objectives) to the extent to which they 'interpenetrate organizations when they establish laws and regulations governing organizational policies and practices' (PEARCE, 2001, p. 12); (b) erraticpredictable: NFG are erratic because they do not succeed in warranting the necessary stability to ensure property rights and the respective punishment of those who promote contract breaches; and (c) weak - strong: NFG are weak on the enforcement of the law because the political bargaining of government offices selects government officials not by merit but by patronage.

Turbulence from NFG is felt by foreign organizations that operate in these countries, which must deal with 'corruption, fragile and unstable laws, exotic (to their point of view) organizational practices and managerial styles' (WOOD JR.; CALDAS, 1998, p. 8); with 'the intrusion of politics into business affairs in conditions where there is often political instability at the macro-level and uncertainty because of corruption at the micro-level' (KOHN; AUSTIN apud CHILD; FAULKNER, 1998 , p. 260); with cultural aspects of the workplace, like centralization of decision-making, discomfort in impersonal and formal settings and priority to social contacts rather than to tasks (RODRIGUES, 1996); and also with the frequent difference between the 'actual behavior and the way this behavior should be by norm, considering that such a difference does not imply punishment to the perpetrator' (MOTTA; ALCADIPANI, 1999, p. 9).

NFG not only affect organizing but also strategizing. Austin (1990) describes how government shapes the competitive environment in developing countries and suggests alternative bargaining strategies. Although the author adopts a more Economic view of this 'political' bargaining, it is a signal of its relevance to do business in such environments.

Some of these characteristics may be noticed in the Brazilian context and, therefore, affect the way local firms behave. It is notorious that, since the 80 's, several plans for inflation control and economic stabilization have changed contractual relations among economic agents, monetary policies, credit available for demand and production, and even the currency (BAER, 1996). From the success of the Real Plan in 1994 to date, environmental conditions have not been less different (either in a factual or perceived standpoint). According to Brito and Vasconcelos (2003b), the 90's were a decade of reforms for the Brazilian economy. The authors pointed out relevant events in the Brazilian economy from 1998 to 2001, including privatization of state-controlled companies, high interest rates, the valuation of the Real against the US Dollar, changes in exchange rate policies that allowed it to float freely and an electric energy crisis that caused the government to issue a rationing plan. 


\section{Organizing and Strategizing in Turbulent Environments}

In this environment, the problem of dealing with hostile, erratic and weak governments is more relevant to managers than the one of facing rapidly changing technologies and aggressive moves from competitors. In a 14-year longitudinal study into the transforming eastern European countries and China, Pearce (2001) points out that, under NFG, organizing around personal relationships with the powerful is the only viable form of organizational survival, since they provide protection and useful information not freely available to all.

However, as remarked by Pearce (2001), this kind of relationship is not based on the usual concept of trust, as found in the literature, in which honesty and cordiality are pre-requisites to building a good reputation and to generating trust. "Although there are many definitions of trust, they tend to agree that it refers to the willingness of one party to relate with another in the belief that the other's action will be beneficial rather than detrimental to the first party, even though this cannot be guaranteed' (CHILD; FAULKNER, 1998, p. 45). Rather, the nature of these relationships is based on the concept of 'mutual hostages'. 'This is not the positive view of trust among friends [...] but rather, closed circles that develop in the face of vulnerability and fear' (PEARCE, 2001, p. 37). Both parties are more useful together than separate and, therefore, choose to participate in a mutually-dependent relationship. On one side, power exerted by officials of an erratic and weak government, and, on the other, the need for protection, information and the dependency in managing these relations in order to ensure firm survival and competitiveness. 'Emphasis on the importance of taking the time to build personal relationships when conducting business in countries such as Brazil, Mexico, Arabian countries and Asia is a standard feature of international management textbooks' (PEARCE, 2001, p. 40).

Besides trust, the concept of cooperation may also be misleading if one attempts to import it to a particular context such as the Chinese environment. Park and Luo (2001) argue that the impersonal character of the concept of networks of cooperation that prevail in western literature prevent it from grasping the true meaning of the relationship described by the Chinese guanxi (LUO; CHEN, 1996; REDDING, 1990; XIN; PEARCE, 1996). The guanxi are networks of personal contacts that are used in order to benefit from privileges from government and from other organizations. In an empirical research, Park and Luo (2001) found that guanxi is positively associated with an increase in the firm's income, and it is significant to establishing relevant external contacts necessary to ensure efficient competitive positions. As the authors comment, while in the west personal relationships may be a result of repeated successful business transactions, in China, successful transactions are a result of an efficient guanxi.

Another Chinese example of how personal contacts influence strategy is provided by Boisot and Child (1999). The authors found that in order to reduce or to absorb environmental complexity and to be capable of dealing with a wide range of contingencies, organizations employ lobby tactics with government officials and build alliances that it make possible to exchange valuable information as well as share risks.

Useful personal contacts in building valuable political alliances might be understood as part of the social capital of organizations of which heterogeneous distribution is positively correlated with firm performance (BATJARGAL, 2003). An organization's social capital also contributes to the strategy formulation process (OSTGAARD; BIRLEY, 1994) and its exploitation provides better reactions to contingencies in turbulent environments (PARK; LUO, 2001). Building and renewing networks of personal contacts with the powerful (PEARCE, 2001), i.e. 'being on the right side...always', reflects the importance of political aspects of strategy process and content as a critical function to be managed (AUSTIN, 1990; PEARCE, 2001). How much these political alliances matter to firm heterogeneity is discussed in the rest of this paper. 


\section{DATA AND METHODS}

Data, methods and design decisions of this empirical investigation are presented. As in previous studies, only publicly traded firms were considered in the sample. Advantages are data reliability and the fact that these firms are influenced by many aspects of environmental turbulence, such as market expectations. The ECONOMATICA database was used to gather firm performance measures. It has been widely used by investment banks and other financial institutions. Its dataset contains data on public firms traded in Latin America. In this study, only Brazilian firms in 15 sectors were considered. To control for size, only firms with net revenue over $\$ 10$ million was considered. Each firm was treated as a single business unit. Financial institutions and banks were not considered, due to their accounting peculiarities and their high leverage ratios. The final sample consisted of firms in which performance measures were provided for in at least 3 years of a four-year period. The final sample consisted of 607 observations of 177 firms, for the composite measure.

It is assumed that using a composite measure for firm performance is more appropriate because it captures different influences from environmental turbulence. Ambiguities concerning what a firm should maximize (GRANT, 2002) and how this should be measured (WINTER, 1995) have favored this assumption. Then, for each firm $k(1,2, \ldots, 177)$ in industry $i(1,2, \ldots, 15)$, in a year $t(1,2, . ., 4)$, three different performance measures were computed, corresponding to different categories in performance evaluation: operational, value creation and market expectation (Exhibit 1).

\section{Exhibit 1: Measures of Firm Performance}

\begin{tabular}{|c|l|}
\hline Indicator & \multicolumn{1}{c|}{ Definition } \\
\hline LO_AT & $\begin{array}{l}\text { It is the return on total assets not considering any financial aspect. It is the ratio of operational } \\
\text { income to total assets. }\end{array}$ \\
\hline ROE_KE & $\begin{array}{l}\text { It reflects value creation or destruction to shareholders to the extent to which the cost of capital } \\
\text { is subtracted from the computed return on equity. }\end{array}$ \\
\hline P_VPA & $\begin{array}{l}\text { It captures investors' expectations over firm future returns. It is the ratio of the stock price, on } \\
\text { the last business day of the year, to its book value (price-to-book). }\end{array}$ \\
\hline
\end{tabular}

The cost of capital of each firm was not calculated. Instead, the shareholders' cost of opportunity was used to build the value-based performance measure (ROE_KE), following the approach used by Ghemawat (1999).

A factor analysis of principal components (PCA) was applied to reduce data and to form the composite measure. PCA was preferred because the extracted component should capture not only shared variance, but also unique and error variance. The scores of the resulting variate were used as the dependent values $r_{t, i, r, k}$ in the following linear model (Equation 1).

$r_{t, i, r, k}=\mu+\gamma_{t}+\alpha_{i}+\delta_{i, t}+\beta_{r}+\phi_{k}+\varepsilon_{t, i, r, k}$

In which,

$r_{t, i, r, k}=R O E_{-} K E_{t, i, r, k}+P_{-} V P A_{t, i, r, k}+L O \_A T_{t, i, r, k}$

Equation 1 provides a linear model for firm performance with five sources of variation, besides the usual error term $\left(\varepsilon_{t, i, r, k}\right)$ : year $\left(\gamma_{t}\right)$, industry $\left(\alpha_{i}\right)$ and firm $\left(\phi_{k}\right)$ are main effects usually modeled on previous studies. The Interaction term $\left(\delta_{t, i}\right)$ was modeled by Rumelt (1991), Hawawini et al. (2003) and Brito and Vasconcelos (2003b). The difference from previous models is the term named 'politics effects' $\left(\beta_{r}\right)$. This class of effects was introduced into the model of Equation 1 to capture differences in establishing and maintaining valuable political alliances, as discussed previously. 
Measuring these 'political' differences is not an easy task. In this study, a somewhat controversial measure, i. e., the donation of campaign funds in elections, was used as a proxy for political alliances. In Brazil, the fund raising system for election campaigns has its peculiarities, concerning the relationship between firms and candidates. Samuels (2003) conducted an extensive exploratory study into donation for campaign funds in Brazilian elections using data from two elections in the late 90's. He remarks that, unlike the American system, in which the only channel between candidates and firms are formal institutions designed for this purpose, in Brazil candidates are allowed to receive funds directly from any firm. His data showed that the majority of donations to Brazilian candidates come from firms ${ }^{(3)}$.

These findings attribute a great deal of importance to firms during the elections. Samuels (2003) also argues that firm donation is greater in sectors that are particularly vulnerable to government regulation or intervention. He found that firms tend to donate more money to candidates seeking offices that exert major influences over their business. 'Advantages for a construction contractor are greater having a governor as a friend than a representative or a senator' (SAMUELS, 2003, p. 376). The author refers to Bezerra (1999) for a better explanation of the nature of these relationships. In general, Samuels (2003) argues that, "firms in these sectors want to be heard and, therefore, contribute generously' (p. 374).

Another Brazilian peculiarity, highlighted by Samuels (2003), is the more personal character of the donor-candidate relationship in Brazil. This strong personal contact-based relationship makes the intention of campaign financing more service-induced than policy-induced. While the former implies that donors of these funds expect some sort of direct 'payment' in exchange, the latter implies that donors expect positive changes in public policies, like the abortion and gun control issues. According to Samuels (2003), in Brazil 'campaign donors expect some specific 'service' that only a government official is able to provide in exchange for his investment' (p. 381). Samuels (2003) draws on Bezerra (1999)'s argument to illustrate these services and provides other anecdotal evidence of mutual privileges.

It is clear then that donation to election campaigns can be a good proxy for what has been defined as politics effects. In the present study, the four-year period covers exactly the period of a term for president, governors, senators ${ }^{(4)}$ and federal representatives. Year $t=1$, is the first year of the term, in which candidates were elected in the elections of the previous year $t=0$.

Official information on firm donations to candidates was used to assign each firm in the sample to one of the three levels of the politics factor: 'donor for the winning candidate', 'donor for the losing candidate' and 'not a donor' ${ }^{(5)}$. This information is public and is officially registered. Any differences that may exist between the official information and the actual amount raised by the candidates are not a problem, because politics effects are categorical measures. What matters is whether a particular firm has donated, or not, and to whom, and not the donated amount. Samuels (2003) defends that official information does not consist of random numbers and consistent patterns can be identified out of these data. In doing so, it is expected that donors are more likely to build and maintain valuable political alliances than a non-donor and that performance differences among firms can be associated to differences in politics factor levels.

In Equation 1, politics effects $\left(\beta_{r}\right)$ are a class of the main effects, and no interaction was modeled, even if this interaction sounds appealing. In fact, as Samuels (2003) suggests, there is an association between sector and office, but the performance variation, associated to this interaction, was distributed among the others modeled effects. Then, the expected performance of a firm $k$, in a particular year $t$, can be described by the total sample average $\mu$, plus the contribution $(\gamma)$ of the year $t$, that affects all firms, plus the specific stable contribution $(\alpha)$ of industry $i$, in which the firm is nested, plus any adjustment $(\delta)$ due to differentiated effects of year $t$ in each particular industry, plus the contribution of the efficiency of its political alliances $(\beta)$, plus the contribution of its own peculiar characteristics $(\phi)$. The error term $\varepsilon_{t, i, r, k}$ captures the difference between the expected and observed firm performance. 
The same two methods used in previous papers to assess the variance were used in the present study: components-of-variance (COV) and hierarchical analysis-of-variance (ANOVA) regression. COV methods estimate variance components for independent, random effects, i.e., drawn from a population of effects from mean zero, unknown variance, and no covariance. This assumption implies that the effects are a natural occurrence of a random sample of a class of effects and that they are not the researcher's artifacts. In this study, the random effect assumption holds true for year, industry, firm and their interactions, but not for the politics effects. The levels of this factor were created by the researchers and cannot be considered as random, but rather, fixed effects.

Thus, Equation 1 was considered a mixed model with one fixed effect (politics) and five random effects (year, industry, industry-year, firm and the error term). Total observed variance of the dependent variable in Equation 1 could be computed from the combination of components of variance related to each random factor (Equation 3).

$\sigma_{r}^{2}=\sigma_{\gamma}^{2}+\sigma_{\alpha}^{2}+\sigma_{\delta}^{2}+\sigma_{\phi}^{2}+\sigma_{\varepsilon}^{2}$

Unbiased estimates for each of these population variances can be calculated using COV methods, such as ANOVA or the iterative process of maximum likelihood (ML). According to Searle (1971), in unbalanced designs, such as this one, the comparison of these methods is a task with great subjectivity. For mixed models, ML is more appropriate, since they estimate variance components for the random effects in the presence of the fixed effects (SEARLE, 1971).

COV methods are considered to be descriptive and do not provide any statistical tests for the significance of the effects. In previous studies, Schmalensee (1985), Rumelt (1991), McGahan and Porter (1997) and Brito and Vasconcelos (2003b) analyzed increments in the explained variance using hierarchical ANOVA under the OLS regression assumption. This method considers all effects as fixed and, by introducing one factor after another, changes in adjusted R-square can be tested for statistical significance, as they are comparable to the results of COV methods. In this stepwise regression, only the residuals of the previous model are considered for regression in the next model, so that early factors tends to capture more variance than the ones that enter in the model last. A discussion on the suitability of COV and hierarchical ANOVA to this kind of research can be found in McGahan and Porter (2002).

Other design decisions must be commented on. In the present study, according to Brito and Vasconcelos (2003b), neither serial correlation nor covariances were modeled, but some portion of the serial correlation may be captured by the interaction term (McGAHAN; PORTER, 1997). Corporate effects were not modeled and firms are to be treated as single business units. Hawawini et al. (2003) did not model corporate effects and argued that their empirical verifications produced ambiguous findings.

A final consideration concerning the treatment of outliers: they are particularly important to this analysis of variance. Hawawini et al. (2003) tested the impact of outliers in variance decomposition of firm performance. They found that when they are excluded from the sample, the relative importance of industry effects tends to increase over the firm effects. To account for this, first, a 'microscopic' screening of the data identified 14 firms with aberrant performance values. Each case was analyzed and then assessed for exclusion. Some of these firms showed large debts or too low-income figures due to process of restructuring or even bankruptcy. Then, for each dependent variable, firms whose performance fell outside the plus or minus 3 standard deviations from the overall average were removed. 


\section{RESULTS AND DISCUSSION}

In this section, data analysis is done in three steps: first, a descriptive analysis of all dependent variables is conducted, then results of principal component analysis is shown and, finally, components of variance and the Hierarchical ANOVA results are analyzed. The final sample consists of 607 observations, for the composite measure, of 177 firms. Table 1 shows the frequency of each original variable and each politics factor level by the levels of industry.

Table 1: Number of Observations by Industry Factor Level

\begin{tabular}{cccccccc}
\hline Brief description of sectors & \multicolumn{3}{c}{ Dependent variables } & \multicolumn{3}{c}{ Politics Factor Levels ${ }^{\#}$} \\
(Industry factor levels) & LO_AT & ROE_KE & P_VPA & 0 & 1 & 2 \\
Agribusiness & 43 & 39 & 42 & 8 & 8 & 32 \\
Wholesale and Retail & 25 & 26 & 25 & 0 & 8 & 20 \\
Construction & 31 & 27 & 31 & 0 & 0 & 32 \\
Electric devices and electronic parts & 24 & 24 & 23 & 4 & 8 & 12 \\
Electric energy generation and distribution & 60 & 53 & 59 & 0 & 0 & 60 \\
Machinery and industrial equipment & 24 & 20 & 24 & 0 & 8 & 16 \\
Mining & 12 & 11 & 12 & 0 & 4 & 12 \\
Non-Metallic Mining & 14 & 11 & 14 & 0 & 12 & 0 \\
Paper and Cellulose & 32 & 30 & 32 & 0 & 24 & 8 \\
Oil and Gas Derivatives & 28 & 24 & 27 & 0 & 8 & 20 \\
Fertilizers and other chemical products & 79 & 74 & 76 & 4 & 16 & 64 \\
Steel and Alluminium Manufactures & 90 & 85 & 90 & 4 & 32 & 60 \\
Telephone, data network providers & 98 & 99 & 98 & 0 & 0 & 112 \\
Fabric, clothing, shoe manufactures & 60 & 56 & 57 & 0 & 24 & 36 \\
Vehicles and auto parts manufactures & 49 & 45 & 47 & 4 & 4 & 44 \\
TOTAL & 669 & 624 & 657 & 24 & 156 & 528 \\
\hline
\end{tabular}

\# $0=$ 'donor for the loosing candidate'; 1 = 'donor for the wining candidate'; $2=$ 'not a donor'.

Table 2 provides descriptive statistics for the dependent variables. Low average values reflect a poor overall performance of sampled firms within the four-year frame.

Table 2: Descriptive Statistics for the Dependent Variables

\begin{tabular}{ccccc}
\hline Variables & Mean & Variance & Skewness & Kurtosis \\
\hline LO_AT & 0,01995 & 0,0139 & $-1,783$ & 9,868 \\
ROE_KE & $-0,22148$ & 0,1940 & $-3,552$ & 18,413 \\
P_VPA & 0,88974 & 0,8820 & 1,908 & 13,743 \\
\hline
\end{tabular}

Overall performance measured by LO_AT is just $1.99 \%$, which is lower than the figures presented by Rumelt (1991), 13\%, and by McGahan and Porter (1997), 9.3\%. Curiously, total observed variance of 0,0139 for LO_AT is lower than values found in foreign studies. The comparison of ROE_KE and LO_AT shows a larger dispersion when financial aspects come into play. The average of P_VPA, lower than 1.00, reflects an overall stock devaluation, compared to their book values. LO_AT statistics for mean and variance are a little lower than the values reported by Brito and Vasconcelos (2003b), $3.8 \%$ and 0,019 , respectively. Finally, skewness and kurtosis statistics show a departure from normality for all variables and characteristics of a leptokurtic distribution, which suggests the tendency of firms performing around average, as well as far way from it, in both directions, favoring negative values. 
The extraction of principal components reduced data capturing shared, unique and error variance of all dependent variables. All partial correlation coefficients were significant $(\mathrm{p}<0,0001)$ and the lowest values were found for P_VPA, which reflect a low association between actual firm performance and investors' expectations. Overall value for the Measure of Sampling Adequacy (MSA) was 0.536. MSA for no variable was above the threshold of 0.50, suggested by Hair et al. (1995). Barlett's Test of Sphericity was found to be significant $(\mathrm{p}<0,0001)$. Just one component (FACTOR1), which accounted for $56.25 \%$ of total variance, was extracted through a non-rotated solution. Table 3 shows the factor loadings for each variable.

Table 3: Factor Loadings to FACTOR1 for Each Original Variable

\begin{tabular}{cc}
\hline Variables & FACTOR1 \\
\hline LO_AT & 0,871 \\
ROE_KE & 0,862 \\
P_VPA & 0,431 \\
\hline
\end{tabular}

FATOR1 was used as the dependent variable of Equation 1. COV analysis and Maximum Likelihood (ML) procedures were used to estimate variance components. The results for the mixed model (Equation 1) and for the variance structure reported by Brito and Vasconcelos (2003b) are presented in Table 4.

Table 4: Components of Variance for Equation 1 Compared to other Brazilian Model

\begin{tabular}{ccc}
\hline Factors & Mixed model & $\begin{array}{c}\text { Brito and Vasconcelos (2003b) } \\
\text { (Random model) }\end{array}$ \\
& ML & ML \\
\hline Year & $0.85 \%$ & $0 \%$ \\
Industry & $2.55 \%$ & $4.3 \%$ \\
Industry-year & $5.05 \%$ & $2.4 \%$ \\
Politics & $\mathrm{N} / \mathrm{A}$ & $\mathrm{N} / \mathrm{A}$ \\
Firm & $44.61 \%$ & $54 \%$ \\
\hline Model & $53.06 \%$ & $60.7 \%$ \\
\hline Error & $46.96 \%$ & $39.30 \%$ \\
\hline
\end{tabular}

Note\#1: Total values may not add because of rounding.

Note\#2: Mixed Model: FACTOR1 = Intercept + Year + Industry + Industry-year + Politics (Fixed) + Firm

Results for the mixed model are computations of variance estimates for random effects, considering the presence of the fixed politics effects. If the initial assumption concerning the importance of politics effects were true, then it would be expected that, in their presence, variance components of firm and error were lower than their values in previous studies. By comparing the results from the mixed model and the ones reported by Brito and Vasconcelos (2003b), one may infer that the presence of politics effects did not produce any significant changes. Firm effects still capture most of total observed variance, followed by industry and year.

However, two aspects are worth noting. First, the mixed model accounts for $53 \%$ of total variance. These figures are around 8\% lower than Brito and Vasconcelos (2003b). If one assumes that a multivariate metric for the dependent variable is more suitable for capturing most of the environmental turbulence influence over different aspects of firm performance, then the model needs further specification.

While these unknown factors need to be identified in future research, the second aspect can shed some light on this issue. The relationship between stable and transient industry effects is different 
throughout the models. While the mixed model results indicate that transient industry effects are more important than stable effects, Brito and Vasconcelos (2003b)'s random model shows the opposite. Nonetheless, this cannot be attributed to the presence of politics effects, because results from a random effect model without politics effects showed the same relationship ${ }^{(6)}$. In fact, this difference is due to the multivariate measurement of firm performance (FACTOR1) in contrast to the univariate measure, LO_AT, used in Brito and Vasconcelos (2003b). A closer examination of FACTOR1, by analyzing the variance components of its original variables, reveals, for ROE_KE, the same relationship pattern between stable and transient industry effects. These findings suggest that when cost of capital comes into play, a different pattern in variance structure may emerge, in which year effects are important to the extent that they affect industries differently. In other words, in turbulent environments, one may argue that there is no such thing as stable industry effects, and what really matters, concerning industry characteristics, is their ability to 'buffer' environmental turbulence caused by yearly macroeconomic fluctuations ${ }^{(7)}$.

Hierarchical ANOVA results confirm the findings derived from COV method. In order to deliver comparable results to Brito and Vasconcelos (2003b), the model was regressed using the same order of entry and omitting transient effects. According to the nesting characteristic of this design, politics factor was included before firm factor. Table 5 shows that year $(p=0,4586)$ and politics effects $(p=0,1311)$ did not cause any significant contribution to the explanatory power. The full model and the other effects were found to be significant at all levels (apart from industry effects, significant at 5\%).

Table 5: Hierarchical ANOVA Results

\begin{tabular}{ccccc}
\hline Factors & R2 change & Adj. R2 change & F - Adj. R2 change & p-value \\
\hline Year & $1,10 \%$ & $0,60 \%$ & 0,908 & 0,4586 \\
Industry & $7,50 \%$ & $5,40 \%$ & 2,248 & 0,0045 \\
Politics & $1,20 \%$ & $0,90 \%$ & 1,882 & 0,1315 \\
Firm & $53,90 \%$ & $41,60 \%$ & 1,857 & 0,0000 \\
Full Model & $63,70 \%$ & $48,50 \%$ & 1,926 & 0,0000 \\
\hline
\end{tabular}

Note: Dependent variable is FACTOR1.

Finally, post hoc comparisons, in a multivariate analysis of variance (MANOVA), were conducted to test for differences between average performances across the levels of politics, for each dependent variable. Tamhane's T2 tests (conservative pairwise comparisons tests based on a t test), under the unequal variance assumption among the three groups, indicated that firms who were more likely to develop valuable political alliances ('donors for the winning candidate') performed better than firms who were not ('not a donor'), for ROE_KE as the dependent variable $(p=0,048)$. The other performance variables did not show significant difference across the three groups. These findings and $\mathrm{COV}$ analysis may suggest that ROE_KE is an important variable, which is more sensitive than others to the effects of environmental turbulence.

\section{CONCLUSIONS}

The initial assumption that, in turbulent environments, the largest component of variance, usually associated with firm effects, could be attributed to firm differences in establishing and maintaining valuable political alliances does not hold. No evidence was found, in these particular data, to support that it could be so. Therefore, the assumption that firm effect variance component is due to firm differences in competitive-like abilities, is still accepted for turbulent environments.

However, these findings are not conclusive and need to be taken cautiously, for several reasons. The sample has limitations. There were not enough data to make a complete factorial design and some cells were empty (Table 1). In this unbalanced design, it would be difficult to model interaction between 
politics and industry effects, which is soundly conceptual (SAMUELS, 2003). As a consequence, the interaction term industry-year may have captured these uncontrolled industry-politics interaction.

Although the operational definition of the construct 'politics effects', by using the donation status in an election campaign as a proxy measure, has generated interesting results, it may not be the most appropriate. The ability to form and to manage political alliances are a unique resource of a firm, which is based on personal contact networks and on the bargaining of personal and firm interests. Despite being of a personal nature, these alliances can be understood as highly contextual within the firm, since firm executives use their personal network as a starting point to develop a relationship in order to trade and bargain organizational resources with others. If one considers this political ability as a resource from the standpoint of the RBV (BARNEY, 1986, 1991; DIERICKX; COOL, 1989; DOSI; NELSON; WINTER, 2000; PETERAF, 1993; WERNEFELT, 1984), then its operational definition as a construct is this research is even more inappropriate, because grouping the firms in just three levels could diminish the contribution of the effect.

Despite these limitations, two insights can be drawn from the results. First, if one assumes the importance for using different performance indicators to capture most of the effects of a turbulent environment, then a more specified model is desirable. The effects of cost of capital were found to provide a significant contribution to this future specification, mainly when one considers the differentiated effects of yearly macroeconomic fluctuations across industries. This result differs significantly from a similar study of Hawawini et al. (2003) for the American economy.

Second, the average performance of firms that are more likely to manage valuable political alliances are significantly higher than the group of firms who do not have this ability, according to the proxy measure firm donation. These findings are an indication that the political alliances hypothesis should be pursued in future studies. Influences of a non-facilitative government (PEARCE, 2001) in firm heterogeneity are yet to be found.

\section{NOTES}

\footnotetext{
${ }^{1}$ An earlier version of this paper received "The Best Paper Award" from the Associação Nacional de Pós-Graduação e Pesquisa em Administração (ANPAD) during their Annual Meeting in 2004 (2004 EnANPAD). The authors are specially grateful to Professor David Samuels, for providing us the complete official data on firm donations; to the Programa de Bolsas de Iniciação Científica - PROBIC of the Universidade do Vale do Itajaí (UNIVALI), for providing us all needed resources; and for comments received on this research at the 2004 EnANPAD, specially from Julian Borba, Luiz Artur Brito, Flávio Carvalho de Vasconcelos, Sergio Giovanetti Lazzarini, Walter Fernando Araújo de Moraes and Jorge Ferreira da Silva. The authors' names are in alphabetical order, reflecting equal efforts.

${ }^{2}$ Actually he used the term 'firm effect', which was redefined later by Rumelt (1991) to 'corporate effect'.

${ }^{3}$ Despite legal limitations of the donated amount; in fact, there is no real limit. As an example, in the data on presidential campaigns in 1994, he found 261donations over US\$ 50,000.00, including 58 over US\$200,000.00.

${ }^{4}$ Although the term of a senator is eight years, they are alternate and there are elections every four years.

${ }^{5}$ Some firms have donated to more than one candidate. The candidate who received the largest amount was considered for classification purposes.

${ }^{6}$ Indeed, when politics effects are included into the model, the difference in favor of transient industry effects are slightly higher.

${ }^{7}$ Although variation in industry performance can also be attributed to some endogenous sources, this paper focuses on exogenous sources of variation, such as the negative influences of government at all levels on businesses affairs.
} 


\section{REFERENCES}

AUSTIN, J. Managing in developing countries: strategic analysis and operating techniques. 1th ed. New York: The Free Press, 1990. p. 465.

BAER, W. A economia brasileira. 4. ed. São Paulo: Nobel, 1996. p. 416.

BARNEY, J. B. Strategic factor markets: expectations, luck, and business strategy. Management Science, Linthicum, MD, v. 32, n. 10, p. 1231-1241, oct. 1986.

. Firm resources and sustained competitive advantage. Journal of Management, Bloomington, v. 17, n. 1, p. 99-120, mar. 1991.

BATJARGAL, B. Social capital and entrepreneurial performance in Russia: a longitudinal study. Organization Studies. Berlin, v. 24, n. 4, p. 535-556, 2003.

BEZERRA, M. O. Em nome das 'bases': política, favor e dependência pessoal. 1. ed. Rio de Janeiro, Relume Dumará/Núcleo de Antropologia da Política, 1999. p. 274.

BOISOT, M.; CHILD, J. Organizations as adaptive systems in complex environments: the case of China. Organization Science, Linthicum, v. 10, n. 3, p. 237-252, may/june 1999.

BRITO, L. A. L.; VASCONCELOS, F. C. How much does country matter. In: ENCONTRO ANUAL DA ANPAD, 27., 2003, Atibaia. Anais... Atibaia: ANPAD, 2003a. CD-ROM.

Firm Performance in an extremely environment: year, industry and firm effects. In: ENCONTRO ANUAL DA ANPAD, 27., 2003, Atibaia. Anais...Atibaia: ANPAD, 2003b. CDROM.

BROWN, J.; EINSENHARDT, K. Competing on the edge: strategy as structured chaos. 1th ed. Boston: Harvard School Press, 1998. p. 320.

CAVES, R.; PORTER, M. From entry barriers to mobility barriers. Quarterly Journal of Economics. Cambridge, v. 91, p. 241-161, 1977.

CHILD; J; FAULKNER, D. Strategies of co-operation: managing alliances, networks and joint ventures. 1th ed. Oxford: Oxford University Press, 1998. p. 371.

DIERICKX, I.; COOL, K. Asset stock accumulation and sustainability of competitive advantage. Management Science. Linthicum, v. 33, n. 12, dec. 1989.

DOSI, G.; NELSON, R.; WINTER, S. (Org.) The nature and dynamics of organizational capabilities. 1th ed. New York: Oxford University Press, 2000. p. 389.

EMERY, F.; TRIST, E. The causal texture of organizational environments. Human Relations, New York, v. 18, n. 1, p. 21-32, 1965.

GHEMAWAT, P. Strategy and the business landscape: text and cases. 1th ed. Frennce-hall, 1999. p. 464.

GRANT, R. M. Contemporary strategy analysis: concepts, techniques, applications. 4th ed. Padstow: Blackwell Publishing, 2002. p. 551.

HAIR, J. et al. Multivariate data analysis. 5th ed. Englewoods Cliffs: Prentice-hall, 1995.

HAWAWINI, G.; SUBRAMANIAN, V.; VERDIN, P. Is performance driven by industry - or firmspecific factors? A new look at the evidence. Strategic Management Journal, Chichester, v. 24, n. 1, p. 1-16. jan. 2003.

LUO, Y.; CHEN, M. Managerial implications of guanxi-based business strategies. Journal of International Management, v. 2, n. 2, p. 193-216, 1996.

McGAHAN, A. M; PORTER, M. E. How much does industry matter, really? Strategic Management Journal. Chichester, v. 18, n. 1, p. 15-30, Summer Special Issue 1997. 
What do we know about variance in accounting profitability? Management Science. Linthicum, v. 48, n. 7, p. 834-851, jul. 2002.

MERZ, G.; SAUBER, M. Profiles of managerial activities in small firms. Strategic Management Journal. Chichester, v. 16, n. 7, p. 551-564, oct. 1995.

MINTZBERG, H.; AHLSTRAND, B.; LAMPEL, J. Strategy safari: a guided tour through the wilds of strategic management. 1th ed. New York: The Free Press, 1998. p. 406.

MOTTA, F.; ALCADIPANI, R. Jeitinho brasileiro, controle social e competição. Revista de Administração de Empresas. São Paulo, v. 39, n. 1, p. 6-12, jan./mar. 1999.

NELSON, R.; WINTER, S. An evolutionary theory of economic change. 1th ed. Cambridge: Harvard University Press, 1982. p. 437.

OSTER, S. Modern Competitive Analysis. 1 th ed. New York: Oxford University Press, 1990.

OSTGAARD, T; BIRLEY, S. Personal networks and firm competitive strategy: a strategic or coincidental match? Journal of Business Venturing. New York, v. 9, n. 4, p. 281-305, july 1994.

PARK, S.; LUO, Y. Guanxi and organizational dynamics: organizational networking in Chinese firms. Strategic Management Journal. Chichester, v. 22, n. 5, p. 455-457, may 2001.

PEARCE, J. Organization and management in the embrace of government. 1 th ed. Mahwah, New Jersey: LEA, 2001. p. 162.

PETERAF, M. The cornerstones of competitive advantage: a resource-based view. Strategic Management Journal. Chichester, v. 14. p. 179-191, 1993.

PORTER, M. Competitive strategy. 1 th ed. New York: Free Press, 1980.

PRAHALAD, C.; HAMEL, G. The core competence of the corporation. Harvard Business Review. Boston, v. 68, n. 3, p. 79-91, mai./jun. 1990.

REDDING, S. The spirit of Chinese capitalism. New York: Walter de Gruyter, 1990.

RODRIGUES, S. Management in Brazil. In: WARNER, M. (Ed.) International Encyclopedia of Business and Management. 1th ed. London: Routledge, 1996. p. 2673-82.

ROQUEBERT, J. A.; PHILLIPS, R. L.; WESTFALL, P. A. Markets vs. management: what drives profitability? Strategic Management Journal. Chichester, v. 17, n. 8, p. 653-664, oct. 1996.

RUMELT, R. P. How much does industry matter? Strategic Management Journal. Chichester, v. 12, n. 3, p. 167-185, mar. 1991.

RUMELT, R. P; SCHENDEL, D.; TEECE, D. Fundamental issues in strategy. Cambridge: Harvard Business School Press, 1994.

SAMUELS, D. Financiamento de campanha e eleições no Brasil. In: BENEVIDES, M. V.; VANNUCHI, P.; KERCHE, F. Reforma Política e Cidadania. 1. ed. São Paulo: Editora Fundação Perseu Abramo, 2003. p. 364-391.

SCHMALENSEE, R. Do markets differ much? The American Economic Review. [S.L.], v. 75, n. 3, p. 341-351, 1985.

SEARLE, S. Linear Models. 1 th ed. Jonh Wiley: New York, 1971.

WERNERFELT, B. A resource-based view of the firm. Strategic Management Journal. Chichester, v. 5, n.2, p. 171-180, feb. 1984.

WINTER, S. G. Four Rs of Profitability: rents, resources, routines and replication. In: MONTGOMERY, C. Resource-based and evolutionary theories of the firm: towards a synthesis. 1 th ed. Kluwer Academic Publishers, 1995. p. 288. 
WOOD JR., T.; CALDAS, M. Antropofagia organizacional. Revista de Administração de Empresas. São Paulo, v.38, n. 4, p. 6-17, out/dez. 1998.

XIN, K.; PEARCE, J. Guanxi: connections as substitutes for formal institutional support. Academy of Management Journal. Briarcliff Manor, v. 39, n. 6, p. 1641-1658, dec. 1996. 